fournal of Medical Genetics (1976). 13, 516-539.

\section{Triple X female and Turner's syndrome offspring}

\begin{abstract}
Summary. A mentally retarded young female having 47 chromosomes with a triple $\mathrm{X}$ karyotype produced a child with Turner's syndrome associated with mental deficiency. To our knowledge this is the first example of a triple $\mathrm{X}$ female giving birth to a child with Turner's syndrome.
\end{abstract}

After Jacobs et al (1959) reported the existence of a supernumerary $\mathrm{X}$ chromosome in a female individual several additional cases have been reported (Jacobs et al, 1960; Carr et al, 1972). Most of these patients have shown reduced mental abilities (Sandberg, Crosswhite, and Gordy, 1960; Singer et al, 1972), and yet no other somatic abnormalities in these females have been described in association with the supernumerary $\mathrm{X}$ chromosome. It has been observed that when triple $\mathrm{X}$ females have given birth the offspring have been chromosomally normal (MacLean, Harnden, and Court Brown, 1961); however, there is a previous report (Singer et al, 1972) of a triple $\mathrm{X}$ female producing a child with Down's syndrome. The present report deals with a case of triple $\mathrm{X}$ female bearing a child with Turner's syndrome.

\section{Case report}

The patient was 28 years of age, mentally deficient. Her height was $1.60 \mathrm{~m}$ and weight $56 \mathrm{~kg}$. There was nothing unusual about her physical features. She had a normal menstrual history and conceived at 21 years, her only pregnancy. The family history was irrelevant.

The child was 7 years old. No information of weight and height at birth was available. Her present height was $125 \mathrm{~cm}$, and weight $22 \mathrm{~kg}$. The nucal hairline and ears were low set. Bilateral epicanthic folds are present. The neck was discretely webbed. The thorax was moderately shield shaped, with separated nipples; no signs of aortic coarctation were present. The external genitalia were of infantile type.
Dermatoglyphs. Dermatoglyphs of both propositi are summarized in the Table. The mother's dermatoglyphs were in accord with the presence of an extra X chromosome. Dermatoglyphs of the child showed no abnormalities.

Cytogenetic study. The analysis of 100 buccal cells contained a chromatin body in $18 \%$ and two Barr bodies in $12 \%$ of the cells. The child had positive sex chromatin in $15 \%$ of the cells analysed. Chromosomal analyses were performed on peripheral leucocytes cultured according to the method of Moorhead et al (1960). The mother had 47 chromosomes with a triple $\mathrm{X}$ karyotype (Fig. 1). In the child, a total of 100 metaphases were studied. She had a 45,X karyotype (Fig. 2).

Because of the results obtained in the chromatin analysis, it was necessary to consider the possibility that the mother might be a mosaic $46, \mathrm{XX} / 47, \mathrm{XXX}$, and the offspring might also be a mosaic $46, \mathrm{XX} / 45, \mathrm{X}$.

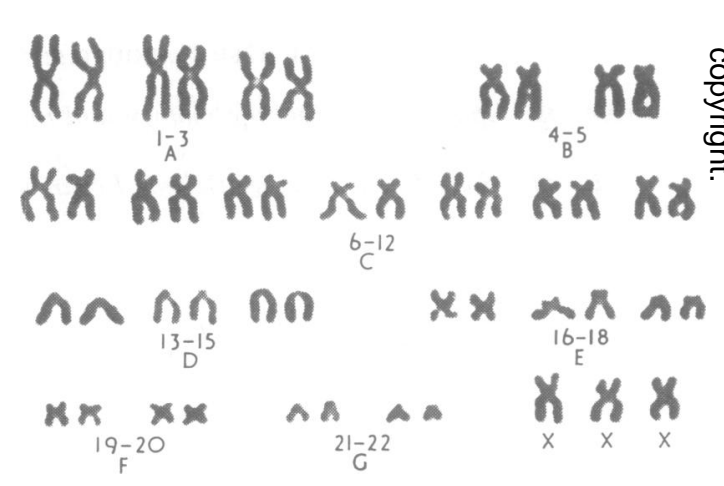

Fig. 1. The 47, XXX karyotype corresponding to the mother.

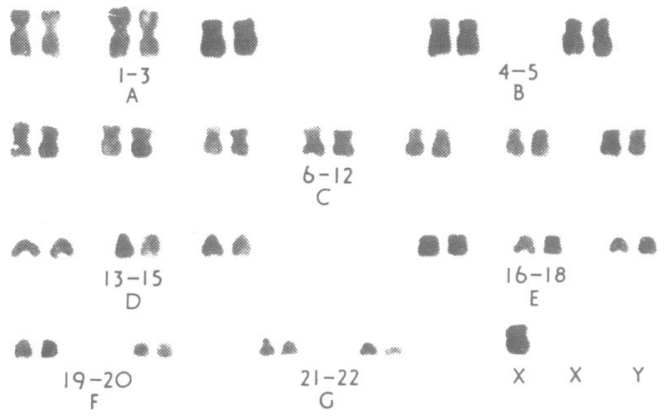

FIG. 2. The $45, \mathrm{X}$ karyotype of the child with Turner's phenotype. 
TABLE

DERMATOGLYPHS

\begin{tabular}{|c|c|c|c|c|c|c|c|c|c|c|c|c|}
\hline \multirow[b]{3}{*}{ Mother } & \multicolumn{6}{|c|}{ Digits } & \multicolumn{6}{|c|}{ Palms } \\
\hline & & 1 & 2 & 3 & 4 & 5 & \multirow[b]{2}{*}{ Mother } & \multicolumn{3}{|c|}{$\begin{array}{ll}T_{1-1} & I_{2}\end{array}$} & $I_{3}$ & $I_{4}$ \\
\hline & $\begin{array}{l}\mathbf{R} \\
\mathbf{L}\end{array}$ & $\underset{\mathbf{U}}{\mathbf{U}}$ & $\underset{\mathbf{U}}{\mathbf{U}}$ & $\underset{\mathrm{U}}{\mathrm{U}}$ & $\begin{array}{l}\mathbf{A} \\
\mathbf{A}\end{array}$ & $\underset{\mathbf{U}}{\mathbf{U}}$ & & $\begin{array}{l}\mathbf{R} \\
\mathbf{L}\end{array}$ & $\stackrel{\mathrm{O}}{\mathrm{O}}$ & $\begin{array}{l}\mathrm{O} \\
\mathrm{O}\end{array}$ & $\begin{array}{l}\mathrm{O} \\
\mathrm{O}\end{array}$ & $\begin{array}{l}\mathrm{O} \\
\mathrm{O}\end{array}$ \\
\hline Child & $\begin{array}{l}\mathbf{R} \\
\mathbf{L}\end{array}$ & $\underset{U}{U}$ & $\underset{\mathbf{U}}{\mathbf{U}}$ & $\begin{array}{l}\mathrm{U} \\
\mathrm{U}\end{array}$ & $\underset{U}{\mathbf{U}}$ & $\underset{\mathbf{U}}{\mathbf{U}}$ & Child & $\begin{array}{l}\mathbf{R} \\
\mathbf{L}\end{array}$ & $\begin{array}{l}\mathbf{L} \\
\mathbf{L}\end{array}$ & $\stackrel{\mathrm{O}}{\mathrm{O}}$ & $\begin{array}{l}\mathrm{O} \\
\mathrm{O}\end{array}$ & $\underset{\mathrm{L}}{\mathrm{L}}$ \\
\hline
\end{tabular}

R: Right L: Left

\section{Discussion}

It is believed that the occurrence of females with a triple $\mathrm{X}$ karyotype is probably higher than previously suspected. Thus, the woman in our case was discovered after she had given birth to a child with Turner's syndrome. There was nothing about her menstrual history and physical appearance that would have indicated that she possessed an extra $\mathrm{X}$ chromosome. While a number of triple $\mathrm{X}$ females have given birth, the offspring had been chromosomally normal, until Singer et al (1972) reported a triple $\mathrm{X}$ case and a Down's syndrome offspring. The case of the present report is the second example of a triple $\mathrm{X}$ female producing a child with a chromosomal abnormality, and to our knowledge the first case of Turner's syndrome offspring.

In order to afford an explanation for this association we accept the presence of some genetic control over non-disjunction in familial cases possessing mixoploidy. Another explanation that could be considered is a chance occurrence; however, it is impossible at present to show which one of these two explanations is correct.

Rodolfo Guzmán-Toledano, Aquiles Ayala, ARTURo Zarate,* and Miguel JiMENEZ

Department of Gynecologic Endocrinology and Section of Clinical Genetics, Hospital de Gineco Obstetricia No. 1, Instituto Mexicano del Seguro Social, Mexico City, México

\section{REFERENCES}

Carr, D. H., Morishima, A., Barr, M. L., Grumbach, M. M., Luers, T., and Baschann, H. W. (1972). An XO/XX/XXX mosaicism in relationship to gonadal dysgenesis in females. Fournal of Clinical Endocrinology and Metabolism, 22, 671-677.

Jacobs, P. A., Baikie, A. G., Court Brown, W. M., MacGregor, T. N. MacLean, N., and Harnden, D. G. (1959). Evidence for the existence of the human 'superfemale'. Lancet, $2,423-425$.

Jacobs, P. A., Harnden, D. G., Court Brown, W. M., Goldstein, J., Close, H. G., MacGregor, T. N., and MacLean, N. (1960). Abnormalities involving the $\mathrm{X}$ chromosome in women. Lancet, 1, 1213-1216.

* Address reprints requests to Dr A. Zárate, Hospital de GinecoObstetricia No. 1, IMSS, Mancera 222, México 12, D. F., México.
MacLean, N., Harnden, D. G., and Court Brown, W. M. (1961) Abnormalities of sex chromosome constitution in newborn babies. Lancet, 2, 406-408.

Moorhead, P. S., Nowell, P. C., Mellman, W. J., Battips, D. N., and Hungerford, D. A. (1960). Chromosome preparations of leukocytes cultured from human peripheral blood. Experimental Cell Research, 20, 613-620.

Sandberg, A. A., Crosswhite, L. H., and Gordy, E. (1960). Trisomy of a large chromosome. Fournal of the American Medical Association, 174, 221-225.

Singer, J., Sachdeva, S., Smith, G. F., and Hsia, D. Y. Y. (1972). Triple $\mathrm{X}$ female and a Down's syndrome offspring. Fournal of Medical Genetics, 9, 238-239.

\section{Confirmation of trisomy 22 by trypsin-giemsa staining*}

Summary. A small-for-dates male infant with mental retardation, microcephaly, malformed ears, preauricular sinuses, epicanthal folds, micrognathia, congenital heart disease, micropenis, and micropolygyria of the parietal and occipital lobes of the cerebral cortex was shown to have a $47, \mathrm{XY},+22$ karyotype by trypsin-giemsa banding. Review of reported cases confirms that there may be distinctive trisomy 22 syndrome.

Before the advent of banding techniques it was assumed that an extra $G$ group chromosome without signs of the Down syndrome indicated trisomy for chromosome No. 22 (Hsu et al, 1971). Attempts have been made to delineate a clinical syndrome. Banding techniques have shown several examples of partial trisomy 15 (Watson and Gordon, 1974) and four cases with trisomy 22 (Bass, Crandall, and

*This study was supported in part by the Carrie J. Loose Trus and the Victor Speas Trust and by funds from The Children's Mercy Hospital, Kansas City Missouri. 